\title{
Analisis Karakteristik Crackers Hasil Substitusi Tepung Terigu Dengan Tepung Ampas Tahu
}

\section{Analysis of Crackers Characteristic Resulting From The Subtitution of Wheat Flour With Tofu Waste Flour}

\author{
Nurul Charismawaty Sabir, Program Studi Pendidikan Teknologi Pertanian, Universitas \\ Negeri Makassar, email: nurulchaozil1d@gmail.com \\ Lahming, Program Studi Pendidikan Teknologi Pertanian, Universitas Negeri Makassar, \\ email: lahmingmaja@gmail.com \\ Andi Sukainah, Program Studi Pendidikan Teknologi Pertanian, Universitas Negeri \\ Makassar, email: andisukainah@yahoo.com
}

\begin{abstract}
Abstrak
Penelitian ini bertujuan untuk mengetahui kualitas kimia dan tingkat penerimaan panelis secara organoleptik terhadap crackers hasil substitusi tepung terigu dengan tepung ampas tahu. Metode penelitian yang digunakan adalah penelitian kuantitatif dengan pendekatan eksperimen. Penelitian ini menggunakan Rancangan Acak Lengkap (RAL) dengan tiga perlakuan dengan perbandingan tepung terigu dengan tepung ampas tahu yaitu $75 \%: 25 \%$, 50\%:50\%, dan 25\%:75\% dengan 3 kali pengulangan dengan dua tahap. Tahap pertama adalah pembuatan tepung ampas tahu kemudian tahap kedua pembuatan crackers. Variabel yang diamati dalam penelitian ini adalah uji kimia yang meliputi kadar air, kadar abu, protein, karbohidrat, dan serat kasar serta uji organoleptik. Data diolah menggunakan program SPSS versi 21, dengan metode analisis of varians (ANOVA) dan dilanjutkan dengan tes DMRT (Duncan). Hasil Penelitian menunjukkan bahwa penambahan tepung ampas tahu memberikan pengaruh terhadap crackers yang dihasilkan, sehingga ditemukan perlakuan terbaik yakni perlakuan A dengan komposisi $75 \%$ tepung terigu dan $25 \%$ tepung ampas tahu dengan ratarata kadar air 4,56\%, kadar abu 2,46\%, protein $11 \%$, serat kasar 3,65\%, serta karbohidrat $75,45 \%$.
\end{abstract}

Kata Kunci: tepung ampas tahu, crackers ampas tahu, crackers, ampas tahu

\begin{abstract}
This study aims to determine the chemical quality and organoleptic level of panelist acceptance of crackers resulting from the substitution of wheat flour with tofu dregs flour. This research is a quantitative research with an experimental approach. This study uses a Completely Randomized Design (CRD) with three treatments with the ratio of wheat flour and tofu dregs flour, namely 75\%:25\%, 50\%:50\%, and 25\%:75\% with 3 repetitions. This research was carried out in two stages. The first stage is making tofu dregs flour and then the second stage is making crackers. The variables observed in this study were chemical tests which included water content, ash content, protein, carbohydrates, crude fiber and organoleptic tests. Data were processed using SPSS version 21, with the method of analysis of variance (ANOVA) and continued with the DMRT test (Duncan). The results showed that the addition of tofu dregs flour gave effect to the crackers produced, so that the best treatment was found, namely treatment A with a composition of $75 \%$ wheat flour and $25 \%$ tofu dregs flour with average $4,56 \%$ water content, $2,46 \%$ ash content, $11 \%$ protein, 3,65\% crude fiber and $75,45 \%$ carbohydrates.
\end{abstract}

Keywords: tofu dregs flour, tofu crackers, crackers, tofu dregs 


\section{Latar Belakang}

Perkembangan industri pangan yang semakin pesat di Indonesia, juga berimbas dengan meningkatnya cemaran limbah hasil industri, tak terkecuali pabrik tahu. Kuantitas pabrik tahu yang juga menjamur di Indonesia diketahui bahwa masih banyak pabrik tahu yang belum mampu mengelolah limbahnya dengan baik. Selain hanya dijadikan sebagai pakan ternak, sebagian besar pabrik justru hanya membuang limbah hasil produksi tahu yang dapat menyebabkan pencemaran lingkungan.

Ampas tahu sering kali disebut sebagai hasil buangan, ternyata memiliki kandungan gizi cukup tinggi yang belum banyak dimanfaatkan oleh masyarakat. Selain kandungan protein sebanyak $17,72 \%$, kandungan karbohidrat 66,24\% sebagai penyedia energi bagi yang dimiliki ampas tahu, dapat dimanfaatkan untuk dijadikan tepung ampas tahu dan dapat dipakai sebagai bahan untuk membuat berbagai jenis kue dan cake yang biasanya memakai tepung terigu. Menurut Wati (2013), kelebihan lain dari tepung ampas tahu adalah adanya kandungan serat kasar lebih besar dari tepung terigu, sehingga kandungan serat pada tepung ampas tahu ini dapat membantu masyarakat untuk memenuhi kebutuhan serat pada tubuh.

Ampas tahu memiliki kandungan nilai gizi yang masih cukup tinggi karena pada proses pembuatan tahu tidak semua bagian protein bisa diekstrak, lebih-lebih jika menggunakan proses penggilingan sederhana dan tradisional (Suhartini dan Hidayat, 2004). Di sisi lain, kelemahan dari ampas tahu itu sendiri yakni adanya bau langu yang menjadi salah satu faktor utama yang menyebabkan rendahnya tingkat penerimaan masyarakat terhadap produk dari kedelai. Bau langu ini disebabkan karena adanya aktivitas enzim lipoksigenase yang terdapat pada kedelai. Bau langu telah menjadi stigma bagi kebanyakan orang yang telah mengkonsumsi kedelai. Namun, bau langu tersebut dapat diminimalisir dengan metode pengeringan.

Mengadaptasi

kebiasaan masyarakat yang lebih suka mengkonsumsi produk siap saji yang umumnya rendah serat, tepung ampas tahu bisa menjadi pilihan. Tepung ampas tahu dapat menjadi alternatif pengganti tepung terigu dalam membuat produk makanan, misalnya dalam pembuatan biskuit crackers.

Biskuit adalah produk yang diperoleh dengan memanggang adonan dari tepung terigu dengan penambahan bahan makanan lain dan dengan atau tanpa penambahan bahan tambahan pangan yang diizinkan. Penggolongan jenis biskuit dibedakan berdasarkan tekstur dan kekerasan biskuit, perubahan bentuk di dalam oven, sifat adonan, ataupun berdasarkan penanganan adonan sebelum adonan biskuit dicetak (Wijaya, 2010). Biskuit dibagi menjadi 4 (empat) kelompok yaitu biskuit keras, crackers, cookies, dan wafer.

Crackers adalah salah satu produk makanan yang terbuat dari tepung terigu. Crackers banyak ditemukan di pasar dalam bermacam-macam bentuk dan rasa. Seperti halnya biskuit pada umumnya sebagian crackers yang ada di pasar menggunakan bahan baku terigu dari gandum. Akan tetapi crackers dan biskuit memiliki beberapa perbedaan yaitu crackers tidak menggunakan telur sedangkan biscuit menggunakan telur sebagai bahan tambahan dan sebelum dicetak adonan crackers difermentasi sedangkan biskuit tidak difermentasi (Ferazuma, dkk., 2011). 
Crackers termasuk salah satu jenis biskuit yang populer di masyarakat karena mempunyai tekstur yang renyah, praktis dan umur simpannya panjang. crackers adalah jenis biskuit yang berbentuk pipih, terbuat dari adonan keras (hard dough), melalui proses fermentasi, dan rasanya asin-gurih dan renyah, serta jika dipatahkan penampang potongannya berlapis-lapis. Crackers dapat dibuat dengan menggunakan berbagai jenis tepung, termasuk tepung ampas tahu.

Pembuatan crackers dengan memanfaatkan limbah tahu menjadi tepung ampas tahu diharapkan mampu menambah kualitas produk, baik dari segi sensori maupun gizinya sehingga dapat menjadi produk pangan fungsional yang mengandung senyawa yang memiliki fungsi tertentu bermanfaat bagi kesehatan.

\section{Bahan dan Metode}

Adapun bahan dan metode yang digunakan dalam penelitian ini adalah sebagai berikut:

\section{Bahan}

Bahan-bahan yang digunakan dalam penelitian ini yaitu tepung ampas tahu, tepung terigu Cakra Kembar, gula, susu skim, garam, sodium bikarbonat, ragi, shortening, air, minyak sawit dan bahan lain yang digunakan untuk analisis kimia.

\section{Prosedur Penelitian}

\section{a. Pembuatan tepung ampas tahu}

Siapkan ampas tahu sebanyak 5 kg lalu cuci sampai bersih. Selanjutnya, dilakukan pengepresan atau pemerasan secara manual dengan menggunakan tangan untuk mengurangi kandungan air ampas tahu. Kemudian dikeringkan menggunakan cabinet dryer selama 6 jam dengan suhu $60-70^{\circ} \mathrm{C}$. Setelah kering, kemudian dilakukan pemblenderan atau penggilingan menjadi tepung. Kemudian diayak secara manual dengan menggunakan alat tapis 80 mesh.

\section{b. Pembuatan crackers}

Campurkan bahan : tepung terigu dan tepung ampas tahu dengan perbandingan tepung terigu dan tepung ampas tahu yaitu 75\%:25\%, 50\%:50\%, dan 25\%:75\%, gula, susu skim, ragi, garam, Sodium bikarbonat, shortening, minyak sawit lalu dikocok dengan mixer. Tambahkan air dingin secukupnya sampai diperoleh adonan yang kalis. Diamkan adonan untuk proses fermentasi selama 1 jam pada suhu $30^{\circ} \mathrm{C}$. Kemudian adonan dipipihkan dan dicetak dengan ketebalan $0,1 \quad \mathrm{~cm}$. Kemudian dipanggang pada suhu $110{ }^{\circ} \mathrm{C}$ selama 20 menit.

\section{Teknik Pengumpulan Data}

Pengambilan data dilakukan dengan dua jenis pengujian yakni pengujian kimia dan organoleptik. Pengujian secara kimia meliputi aspek kadar air, kadar abu, protein, serat kasar dan karbohidrat. Pengujian secara organoleptik meliputi aspek warna, rasa, tekstur dan aroma. 


\section{Hasil dan Pembahasan}

\section{Rendemen Tepung Ampas Tahu}

Proses pembuatan tepung ampas tahu menggunakan ampas tahu basah yang baru selesai diproduksi dengan penampakan putih kecoklatan dan berbau langu sebanyak 5 kilogram menghasilkan berat sebesar 2,83 kilogram setelah melalui tahapan pencucian dan pengepresan. Kemudian menghasilkan berat kering ampas tahu sebanyak 0,46 kilogram dan menghasilkan tepung ampas tahu sebanyak 0,40 kilogram setelah melalui proses pemblenderan dan pengayakan, sehingga rata-rata rendemen tepung ampas tahu adalah sebesar $8 \%$ dari berat basah ampas tahu.

\section{Analisis Kimia}

\section{a. Kadar Air}

Kadar air adalah banyaknya air yang terkandung dalam bahan pangan yang dinyatakan dalam persen. Air juga merupakan salah satu unsur penting yang mempengaruhi tekstur, penampakan serta cita rasa makanan. Adapun hasil analisis kimia terhadap kandungan kadar air pada cracker hasil substitusi tepung terigu dengan tepung ampas tahu dapat dilihat pada Gambar 4.1.

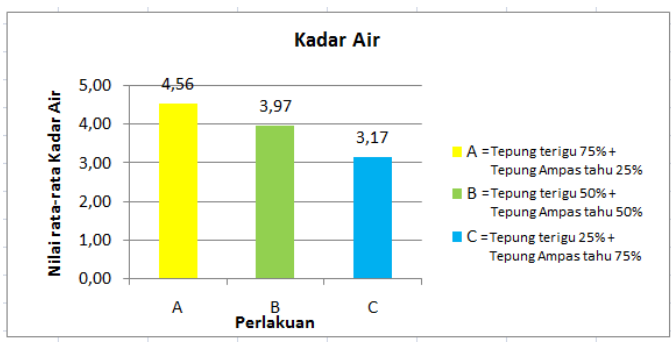

\section{Gambar 4.1 Nilai rata-rata Kadar Air Crackers Ampas Tahu}

Berdasarkan syarat mutu biskuit, kandungan kadar air pada crackers hasil substitusi tepung terigu dengan tepung ampas tahu ditemukan ketiga perlakuan memenuhi SNI yakni maksimal 5\%. Hasil analisis kadar air pada Gambar 4.1 menunjukkan perlakuan A (tepung terigu $75 \%$ + tepung ampas tahu 25\%) dengan kadar air tertinggi dan perlakuan $\mathrm{C}$ (tepung terigu $25 \%$ + tepung ampas tahu $75 \%$ ) dengan kadar air terendah.

Berdasarkan hasil uji lanjut Duncan (DMRT) kadar air crackers, ditemukan perlakuan terbaik yakni perlakuan C (tepung terigu $25 \%$ + tepung ampas tahu $75 \%$ ) dengan jumlah kadar air terendah. Terjadinya penurunan kadar air seiring dengan konsentrasi tepung ampas tahu yang semakin besar disebabkan karena sifat tepung ampas tahu yang tidak mampu membentuk gel, sehingga kemampuan mengikat air dan bahan-bahan lain rendah (Yustina dan Abadi, 2012).

Tinggi rendahnya kadar air suatu bahan pangan, mempengaruhi tekstur suatu produk. Hal ini dipertegas Engelen (2018), semakin menurunnya nilai kadar air maka nilai kekerasan akan semakin tinggi sehingga akan menentukan daya awet dari bahan pangan. Tinggi rendahnya kadar air juga mempengaruhi warna produk. Hal ini dijelaskan Putri (2012) dalam penelitiannya, bahwa semakin rendah kadar air semakin tinggi nilai $\Delta \mathrm{H}^{*}$ yang berarti warna semakin mengarah ke warna yang lebih gelap. Di mana $\Delta \mathrm{H}^{*}$ yang disebutkan merupakan nilai yang digunakan untuk melihat secara keseluruhan perubahan warna.

\section{b. Kadar abu}

Kadar abu atau yang dikenal sebagai zat organik menunjukkan total mineral yang terkandung dalam bahan pangan. Adapun hasil analisis kimia terhadap kadar abu pada crackers dapat dilihat pada Gambar 4.2. 


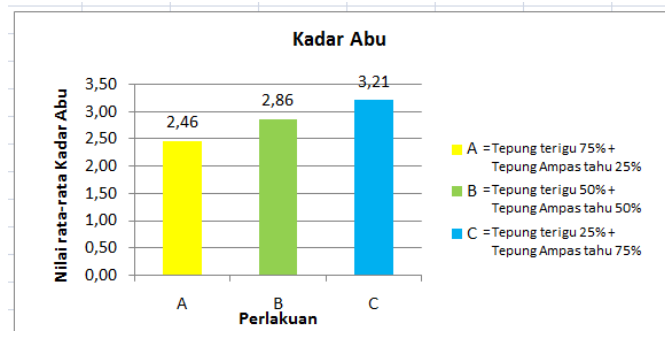

\section{Gambar 4.2 Nilai rata-rata Kadar Abu Crackers Ampas Tahu}

Berdasarkan syarat mutu crackers, kandungan kadar abu pada crackers hasil substitusi tepung terigu dengan tepung ampas tahu, ditemukan ketiga perlakuan melebihi ambang batas syarat SNI yakni maksimal 2\%. Analisis kimia kadar abu pada Gambar 4.2 menunjukkan perlakuan $\mathrm{C}$ (tepung terigu $25 \%$ + tepung ampas tahu $75 \%$ ) dengan kadar abu tertinggi dan perlakuan A (tepung terigu $75 \%$ + tepung ampas tahu 25\%) dengan kadar abu terendah.

Berdasarkan hasil uji lanjut Duncan (DMRT) kadar abu crackers, ditemukan perlakuan terbaik yakni perlakuan A (tepung terigu $75 \%$ + tepung ampas tahu 25\%) dengan kadar abu terendah. Hal ini disebabkan karena perbedaan proporsi penambahan tepung ampas tahu. Semakin rendah penambahan tepung ampas tahu dan semakin tinggi penambahan tepung terigu maka semakin rendah pula kadar abu yang dihasilkan. Hal ini sesuai dengan pendapat Yuliani dan Mardesci (2017) bahwa tingginya kadar abu dapat disebabkan adanya penambahan tepung ampas tahu yang mengandung residu anorganik dalam jumlah besar, karena ukuran partikel tepung ampas tahu yang masih kasar sementara tepung terigu sangat halus, kasarnya tekstur tepung ampas tahu mengakibatkan adanya serat-serat yang berada dalam produk. Selain adanya kandungan mineral pada tepung ampas tahu, kandungan protein yang tinggi menjadi faktor meningkatnya abu pada biskuit.

Tingginya kadar abu pada suatu bahan pangan akan mempengaruhi warna pada produk. Menurut Aufari (2013), pada umumnya mineral tidak terpengaruh oleh adanya proses pengolahan. Selain itu, tidak adanya penambahan bahan-bahan lain di dalam proses pembuatan tepung juga berpengaruh terhadap kadar abu. Penambahan bahan lain dapat memperbanyak kadar abu yang nantinya akan memberikan pengaruh terhadap hasil akhir bahan. Semakin rendah kadar abu pada produk tepung akan semakin baik karena kadar abu mempengaruhi tingkat kestabilan adonan tepung (Lopulalan et al, 2016). Selain untuk mengetahui komponen mineral yang ada dalam bahan pangan, kadar abu juga digunakan untuk mengetahui tingkat kemurnian dari produk tepung karena kadar abu yang tinggi pada tepung kurang disukai karena memiliki warna yang gelap pada produk yang dihasilkan.

\section{c. Protein}

Protein merupakan suatu zat makanan yang sangat penting bagi tubuh, karena dapat berfungsi sebagai bahan bakar, zat pembangun dan pengatur (Winarno, 2004). Adapun hasil analisis kimia terhadap kandungan protein pada crackers hasil substitusi tepung terigu dengan tepung ampas tahu dapat dilihat pada Gambar 4.3.

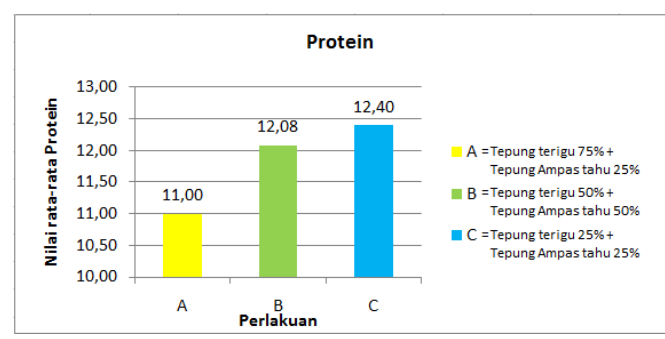

Gambar 4.3 Nilai rata-rata Protein Crackers Ampas Tahu 
Berdasarkan syarat mutu crackers, kandungan protein pada crackers hasil substitusi tepung terigu dengan tepung ampas tahu dengan ketiga perlakuan memenuhi standar SNI yakni minimal $8 \%$. Hasil analisis protein pada Gambar 4.3 menunjukkan perlakuan $\mathrm{C}$ (tepung terigu $25 \%$ + tepung ampas tahu $75 \%$ ) dengan kadar protein tertinggi dan perlakuan A (tepung terigu $75 \%$ + tepung ampas tahu $25 \%$ ) dengan kadar protein terendah.

Berdasarkan hasil uji lanjut Duncan (DMRT) kandungan protein crackers ditemukan perlakuan terbaik yaitu perlakuan C (tepung terigu $25 \%+$ tepung ampas tahu $75 \%$ ) dengan kadar protein tertinggi.

Komposit tepung ampas tahu yang lebih besar pada perlakuan $\mathrm{C}$ (tepung terigu $25 \%$ + tepung ampas tahu $75 \%$ ) menyebabkan kadar protein yang tinggi pula. Sehingga dapat disimpulkan bahwa kadar protein crackers akan meningkat seiring dengan meningkatnya jumlah penambahan tepung ampas tahu. Hal ini sesuai dengan sifat kedelai yang dijelaskan oleh Koswara (1995) bahwa diantara jenis kacang-kacangan, kedelai merupakan sumber protein yang terbaik. Pernyataan ini dijelaskan lebih lanjut oleh Suprapti (2005), bahwa kadar protein pada tepung ampas tahu $23,55 \%$ dan lebih tinggi daripada tepung terigu $8,90 \%$.

Tingginya protein pada suatu bahan pangan mempengaruhi tekstur pada produk. Semakin tinggi kadar protein menyebabkan daya kembang crackers semakin menurun. Sebagaimana dalam penelitian Hayati (2008), bahwa peningkatan proporsi tepung tempe semangit mengakibatkan peningkatan kadar protein, semakin tinggi protein yang terkandung dalam suatu bahan maka bahan tersebut akan semakin sulit melepas air pada suhu pemanasan yang sama. Meningkatnya kadar protein maka akan menurunkan kadar air. Menurunnya kadar air mengakibatkan penurunan daya kembang, karena semakin rendah kadar air mengakibatkan ketersediaan uap air untuk mengembangkan kerupuk juga ikut menurun.

\section{d. Serat Kasar}

Serat kasar merupakan bagian dari pangan yang tidak dapat dihidrolisis namun mampu mengikat air, selulosa dan pektin yang dapat membantu mempercepat proses sekresi dalam saluran pencernaan. Adapun hasil analisis kimia terhadap kandungan serat kasar pada crackers hasil substitusi tepung terigu dengan tepung ampas tahu dapat dilihat pada Gambar 4.4.

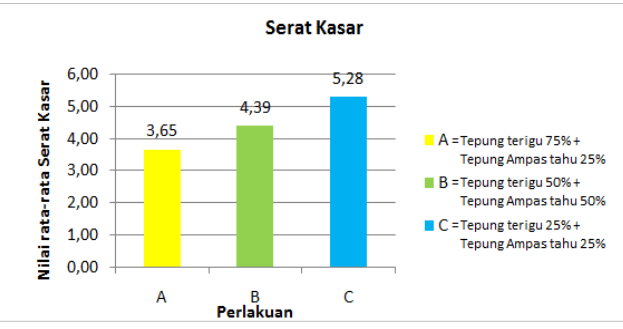

\section{Gambar 4.4 Nilai rata-rata Kadar Serat Kasar Crackers Ampas Tahu}

Berdasarkan hasil analisis kimia terhadap serat kasar pada crackers hasil substitusi tepung terigu dengan tepung ampas tahu, ketiga perlakuan melebihi standar SNI serat kasar yakni maksimum $0,5 \%$. Hasil analisis serat kasar pada Gambar 4.4 menunjukkan perlakuan C (tepung terigu $25 \%$ + tepung ampas tahu $75 \%$ ) dengan kandungan serat kasar tertinggi dan perlakuan A (tepung terigu $75 \%$ + tepung ampas tahu 25\%) dengan kandungan serat kasar terendah.

Berdasarkan hasil uji lanjut Duncan (DMRT) kandungan protein crackers terbaik yaitu perlakuan $\mathrm{C}$ (tepung terigu $25 \%$ + tepung ampas tahu $75 \%$ ) dengan 
kadar serat kasar tertinggi. Hal tersebut dikarenakan tingginya serat kasar yang dimiliki tepung ampas tahu sehingga komposit tepung tahu terbanyak akan menghasilkan serat kasar pula. Meskipun jika ditinjau dari aspek SNI yang melewati standar, namun pengembangan produk ini diharapkan dapat membantu memenuhi kebutuhan serat kasar pada tubuh. Menurut Fransisca (2004), kecukupan asupan serat kini dianjurkan semakin tinggi, mengingat banyak manfaat yang menguntungkan bagi kesehatan tubuh, adequate intake (AI) untuk serat makanan sebagai acuan untuk mennjaga kesehatan saluran pencernaan dan kesehatan laiannya kini telah dikeluarkan oleh Badan Kesehatan Internasional. AI untuk serat bagi orang dewasa adalah 20-35gr/hari.

Tingginya rendahnya serat kasar pada bahan pangan mempengaruhi kualitas tekstur produk. Menurut Hood (1980) dalam Harijono et al. (2012), kadar serat kasar menyebabkan turunnya daya serap air dalam granula pati. Daya serap air yang menurun mengakibatkan proses gelatinisasi pati menjadi tidak sempurna dan menyebabkan tekstur menjadi keras. Hal ini dipertegas Tamtarini dan Yuwanti (2005) bahwa serat sebagai senyawa tidak larut dalam air dan memperkuat jaringan bahan, dalam bahan pangan berfungsi sebagai penguat tekstur.

\section{e. Karbohidrat}

Karbohidrat merupakan zat yang terkandung dalam bahan pangan yang berperan sebagai bahan bakar dalam menjalankan fungsi tubuh manusia. Adapun hasil analisis kimia terhadap kandungan karbohidrat pada crackers hasil substitusi tepung terigu dengan tepung ampas tahu dapat dilihat pada Gambar 4.5.

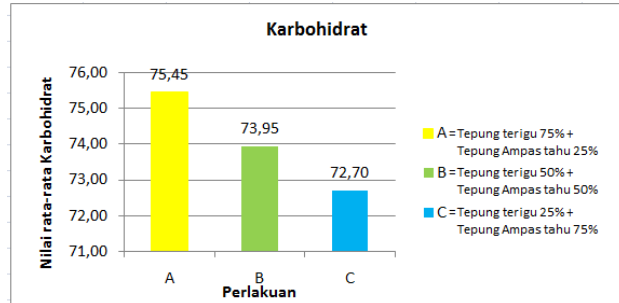

\section{Gambar 4.5 Nilai rata-rata Karbohidrat Crackers Ampas Tahu}

Berdasarkan hasil analisis kimia terhadap karbohidrat, ketiga perlakuan mengalami penurunan karbohidrat. Jika dibandingkan dengan persyaratan minimum kadar karbohidrat sesuai dengan SNI yakni minimal $70 \%$ ketiga perlakuan memenuhi standar. Hasil analisis karbohidrat pada Gambar 4.5 menunjukkan perlakuan A (tepung terigu $75 \%$ + tepung ampas tahu 25\%) dengan kadar karbohidrat tertinggi dan perlakuan $\mathrm{C}$ (tepung terigu $25 \%$ + tepung ampas tahu $75 \%$ ) dengan kadar karbohidrat terendah.

Berdasarkan hasil uji lanjut Duncan (DMRT) kandungan karbohidrat crackers yang dihasilkan, menunjukkan bahwa pada kolom subset memiliki perbedaan, berarti penambahan tepung ampas tahu berpengaruh nyata menurut uji lanjut Duncan (DMRT) pada taraf 5\%. Hasil uji Duncan ditemukan perlakuan terbaik yaitu perlakuan A (tepung terigu $75 \%$ + tepung ampas tahu 25\%).

Terjadinya penurunan karbohidrat seiring dengan jumlah substitusi tepung ampas tahu dikarenakan adanya penggantian tepung terigu sebagai sumber utama karbohidrat dengan tepung ampas tahu yang tinggi protein namun rendah karbohidrat. Hal ini sejalan dengan pendapat Sugito dan Hayati (2006), bahwa kadar karbohidrat yang dihitung secara by difference dipengaruhi oleh komponen nutrisi lain, semakin rendah komponen nutrisi lain maka kadar karbohidrat akan 
semakin tinggi. Begitu juga sebaliknya semakin semakin tinggi komponen nutrisi lain maka kadar karbohidrat akan semakin rendah.

Besarnya komposisi tepung terigu dengan kandungan karbohidrat yang tinggi berbanding lurus dengan jumlah kandungan pati sehingga mempengaruhi tekstur crackers. Hal ini sesuai dengan pendapat Williams (2001) bahwa tepung terigu akan memberikan tekstur yang elastis karena kandungan gluten dan menyediakan tekstur padat setelah dipanggang. Pati merupakan komponen lain yang penting pada tepung terigu dengan tepung lainnya. Air terikat oleh pati ketika terjadi gelatinisasi dan akan hilang pada saat pemanggangan. Hal ini yang menyebabkan adonan berubah menjadi renyah pada produk panggang.

\section{Uji Organoleptik}

Uji organoleptik dilakukan oleh 25 orang panelis dengan parameter pengamatan yaitu warna, aroma dan tekstur. Panelis diminta untuk memberikan nilai berupa tingkat kesukaannya terhadap crackers hasil substitusi tepung terigu dengan tepung ampas tahu yang dihasilkan dengan

menggunakan skala 1-5. Grafik uji hedonik dapat dilihat dari hasil penilaian panelis sebagai berikut:

\section{a. Warna}

Warna merupakan sensori pertama yang dapat dilihat langsung oleh panelis. Tingkat kesukaan panelis terhadap warna pada crackers hasil substitusi tepung terigu dengan tepung ampas tahu dapat dilihat pada Gambar4.6.

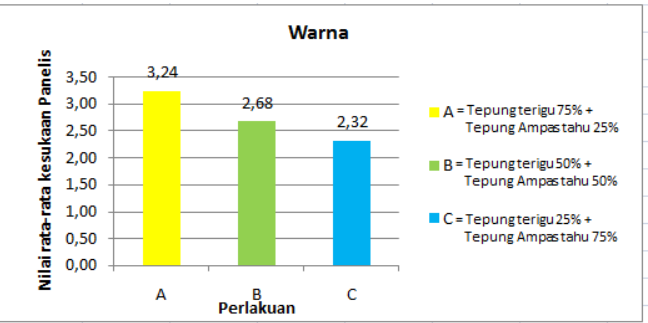

\section{Gambar 4.6 Tingkat Kesukaan Panelis terhadap Warna}

Hasil analisis terhadap warna crackers pada Gambar 4.6 menunjukkan bahwa tingkat kesukaan panelis tertinggi yaitu pada perlakuan A (tepung terigu $75 \%$ + tepung ampas tahu 25\%) dan perlakuan $\mathrm{C}$ (tepung terigu $25 \%+$ tepung ampas tahu 75\%) dengan tingkat kesukaan terendah.

Berdasarkan hasil uji lanjut Duncan (DMRT) ditemukan perlakuan terbaik yaitu perlakuan A (tepung terigu $75 \%+$ tepung ampas tahu 25\%). Perlakuan A (tepung terigu $75 \%$ + tepung ampas tahu $25 \%)$ memiliki warna coklat kekuningan. Sementara perlakuan B (tepung terigu $50 \%$ + tepung ampas tahu 50\%) dan perlakuan $\mathrm{C}$ (tepung terigu $25 \%+$ tepung ampas tahu $75 \%$ ) memiliki warna coklat.

Hal ini disebabkan karena tepung terigu memiliki warna lebih terang dari pada tepung ampas tahu. Sehingga, semakin besar komposit tepung terigu akan memberikan pengaruh warna yang lebih terang. Sebaliknya, semakin besar komposit tepung ampas tahu terhadap produk yang dibuat akan memberikan pengaruh warna produk yang lebih gelap. Hal ini sesuai dengan teori Husin (2013) bahwa warna tepung terigu merupakan faktor penting yang akan berpengaruh langsung terhadap warna kue atau roti yang dihasilkan.

Warna coklat pada crackers disebabkan karena adanya reaksi maillard akibat proses pemanggangan. Hal tersebut sejalan 
dengan pendapat Wahyuni et al., (2017), bahwa reaksi pencoklatan dipengaruhi oleh pemanasan pada suhu tinggi seperti proses pengeringan, penggorengan, pemanggangan, dan pemasakan.

Aspek lain yang mempengaruhi perbedaan warna di tiap perlakuan yakni warna tepung terigu yang lebih terang dan tepung ampas tahu dengan karakteristik warna tepung ampas tahu yang gelap. Pernyataan ini diperkuat oleh Sugiarto (2006), bahwa ciri khas tepung ampas tahu tekstur halus, berbau langu, dan berwarna kecoklatan.

Alternatif untuk memperbaiki tingkat kesukaan panelis terhadap parameter warna dapat dilakukan pemeraman selama beberapa minggu, namun untuk memperoleh waktu yang singkat biasanya dilakukan penambahan Bahan Tambahan Makanan (BTM) berupa zat pemucat (pemutih) tepung seperti Benzil Peroksida sesuai dengan takaran standar. Hal ini diperkuat dengan pendapat Winarno (2002), untuk memperoleh terigu dengan mutu baik, terigu dibiarkan selama lebih kurang enam minggu. Selama masa pemeraman tersebut, bahan-bahan yang menyebabkan sifat lekat dan juga pigmen karotenoid akan teroksidasi sehingga akan diperoleh tepung terigu yang berwarna putih dan dengan daya kembang yang baik. Namun proses pemeraman ini sangat tidak praktis, sehingga untuk mempercepat proses tersebut biasanya ditambahkan zat pemucat. Zat pemucat ini bersifat oksiadator. Ikatan rangkap dalam karotenoid, yaitu xantofil akan dioksidasi. Degradasi pigmen karotenoid akan menghasilkan senyawa yang tidak berwarna.

\section{b. Rasa}

Rasa merupakan salah satu aspek analisis organoleptik yang dihasilkan dari indera perasa manusia. Tingkat kesukaan panelis terhadap rasa pada crackers hasil substitusi tepung terigu dengan tepung ampas tahu dapat dilihat pada Gambar 4.7.

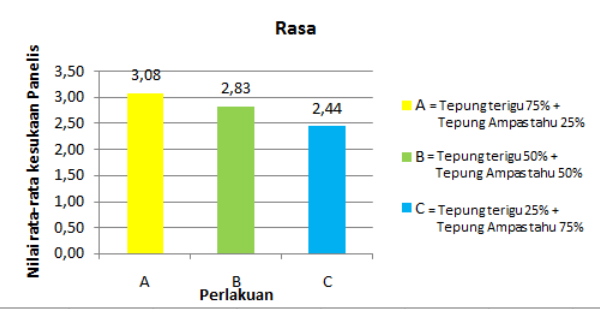

\section{Gambar 4.7 Tingkat Kesukaan Panelis terhadap Rasa}

Pada penelitian ini, analisis kesukaan panelis terhadap rasa crackers paling disukai dijabarkan pada Gambar 4.7 yaitu perlakuan A (tepung terigu $75 \%$ + tepung ampas tahu 25\%) dengan kriteria agak manis. Sementara, B (tepung terigu $50 \%+$ tepung ampas tahu $50 \%$ ) dan $\mathrm{C}$ (tepung terigu $25 \%$ + tepung ampas tahu $75 \%$ ) memiliki kriteria penilaian tidak disukai memiliki kriteria tidak manis.

Berdasarkan hasil uji lanjut Duncan (DMRT) ditemukan perlakuan terbaik yakni perlakuan A (tepung terigu 75\% + tepung ampas tahu 25\%) dengan kriteria agak manis. Hal ini menunjukan penggunaan tepung terigu dengan tepung ampas tahu mempengaruhi rasa yang dihasilkan crackers. Semakin banyak penggunaan tepung terigu maka akan meningkatkan rasa manis. Sebaliknya, semakin banyak penggunaan tepung ampas tahu maka akan mempengaruhi rasa manis yang semakin menurun. Hal ini disebabkan karena kandungan karbohidrat yang tinggi yang terdapat pada tepung terigu dapat menghasilkan rasa manis. Sebagaimana pernyataan ini diperkuat Indriyani (2007), bahwa di dalam karbohidrat terdapat glukosa, sukrosa, dan pati yang dapat meningkatkan cita rasa pada bahan makanan. 
Berbeda dengan crackers dengan komposit tepung ampas tahu yang memiliki rasa tidak manis (pahit). Hal tersebut dipengaruhi oleh sifat tepung ampas tahu yang cenderung pahit sehingga menutupi rasa manis pada produk. Pernyaatan tersebut diperjelas oleh Imaningtias (2008), bahwa off flavor pada formulasi tepung ampas tahu adalah langu, aroma apek, rasa pahit dan getir. Pernyataan ini diperkuat Koswara (1992), kelompok senyawa yang menyebabkan offflavour antara lain penyebab bau langu (beany flavour), penyebab rasa pahit dan penyebab rasa kapur (chalky flavour) sehingga kurang disukai oleh panelis.

Alternatif untuk menambah tingkat kesukaan panelis terhadap parameter rasa dapat dilakukan dengan penambahan Bahan Tambahan Makanan (BTM) berupa zat pemanis alami seperti gula granulasi pada penampang crackers atau penambahan bahan pemanis lainnya untuk memperbaiki rasa. Hal ini sesuai dengan pendapat Silalahi (2011), bahan pemanis ditambahkan dengan tujuan untuk memperbaiki rasa dan bau bahan pangan sehingga rasa manis yang timbul dapat meningkatkan kelezatan.

\section{c. Tekstur}

Tekstur merupakan aspek analisis organoleptik yang dihasilkan melalui sentuhan kulit maupun pencicipan. Tingkat kesukaan panelis terhadap tekstur pada crackers hasil substitusi tepung terigu dengan tepung ampas tahu dapat dilihat pada Gambar 4.8 .

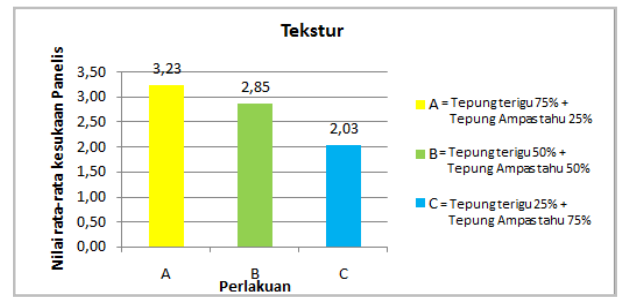

\section{Gambar 4.8 Tingkat Kesukaan Panelis terhadap Tekstur}

Berdasarkan hasil analisis terhadap tekstur crackers pada Gambar 4.8 menunjukkan bahwa sampel tertinggi paling disukai panelis yaitu pada perlakuan A (tepung terigu $75 \%$ + tepung ampas tahu 25\%) netral dengan kriteria kurang renyah, sedangkan perlakuan B (tepung terigu $50 \%$ + tepung ampas tahu $50 \%$ ) dan C (tepung terigu 25\% + tepung ampas tahu $75 \%$ ) kurang disukai dengan kriteria tekstur tidak renyah (keras).

Berdasarkan hasil uji lanjut Duncan (DMRT) ditemukan perlakuan terbaik yaitu perlakuan A (tepung terigu $75 \%$ + tepung ampas tahu 25\%). Hal ini disebabkan karena kandungan gluten yang terdapat pada tepung terigu mempengaruhi daya kembang dan tekstur crackers. Purba (2002), dalam penelitiannya memperjelas bahwa gluten yang ada di dalam tepung terigu bersifat elastis, menggumpal, dan akan mengembang pada saat terigu dibasahi dengan air. Sifat tersebut yang akan menentukan kualitas dari produk biskuit yang dihasilkan.

Tekstur yang keras pada crackers dengan substitusi tepung ampas tahu dipengaruhi oleh kandungan serat kasar yang dimiliki. Hal ini sejalan dengan pendapat Setiaji (2012) yang menyatakan bahwa peningkatan kekerasan flakes yang disubstitusi tepung kedelai disebabkan tingginya kadar serat tepung kedelai sehingga flakes menjadi berkurang porositasnya 
Alternatif untuk menambah tingkat kesukaan panelis terhadap parameter tekstur dapat dilakukan dengan menambahkan margarin. Hal ini diperjelas dalam Oktavia (2007), bahwa penambahan margarin (lemak) yang ada pembuatan cookies akan mengubah tekstur, rasa, dan flavor cookies. Lemak tersebut dapat berinteraksi dengan granula pati dan mencegah hidrasi sehingga peningkatan viskositas bahan menjadi rendah. Pendapat ini juga diperkuat oleh Nurdjanah et al. (2011) bahwa lemak pada dari margarin dan butter akan memecah strukturnya kemudian melapisi pati dan gluten sehingga membantu pengembangan biskuit.

\section{d. Aroma}

Aroma merupakan pengujian organoleptik yang dapat dinilai melalui indera penciuman. Tingkat kesukaan panelis terhadap aroma pada crackers hasil substitusi tepung terigu dengan tepung ampas tahu dapat dilihat pada Gambar 4.9.

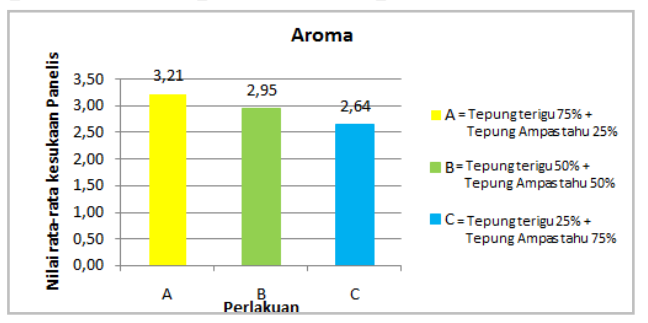

\section{Gambar 4.9 Tingkat Kesukaan Panelis terhadap Aroma}

Berdasarkan analisis terhadap aroma crackers pada Gambar 4.9 didapatkan bahwa perlakuan paling disukai panelis yaitu pada perlakuan A (tepung terigu $75 \%$ + tepung ampas tahu $25 \%$ ) dengan kriteria aroma ampas tahu kurang nyata. Sementara B (tepung terigu 50\% + tepung ampas tahu 50\%) dan $\mathrm{C}$ (tepung terigu $25 \%$ + tepung ampas tahu $75 \%$ ) dinilai kriteria aroma ampas tahu agak nyata.
Berdasarkan hasil uji lanjut Duncan (DMRT) ditemukan perlakuan terbaik yakni perlakuan A (tepung terigu $75 \%+$ tepung ampas tahu 25\%). Hal tersebut disebabkan karena perlakuan memiliki komposit tepung ampas tahu yang lebih sedikit dan tepung terigu yang banyak sehingga apabila kompositnya semakin banyak dan tepung terigu sedikit, akan memberikan aroma cukup nyata ampas tahu. Sebaliknya apabila tepung ampas tahu dikompositkan dalam jumlah sedikit dengan tepung terigu dengan jumlah yang banyak, maka pengaruh aroma ampas tahu semakin kurang nyata. Sebaliknya Hal ini sesuai dengan teori Suhardjito (2005) bahwa tepung terigu mudah menyerap baubau yang ada disekitar.

Crackers dengan substitusi ampas tahu memiliki aroma ampas tahu. Menurut Suliantari dan Winiati (1990) dalam Syafitri (2009) tepung ampas tahu memiliki aroma yang khas yaitu beraroma langu. Hal ini disebabkan karena adanya senyawa lipoksigenase. Menuru Somaatmaja et al. (1964) timbulnya bau langu disebabkan karena adanya aktivitas enzim pada kedelai. Terjadinya bau langu muncul terutama wajtu pengolahan, yaitu setelah tercamournya lipoksigenase dalam lemak kedelai.

\footnotetext{
Alternatif untuk menambah tingkat kesukaan panelis terhadap parameter aroma dapat dilakukan dengan menambahkan Bahan Tambahan Makanan (BTM) berupa senyawa aroma seperti essens. Hal ini dibuktikan dengan penelitian Anggraini (2012), yang menunjukkan bahwa hasil penelitian uji inderawi volume essens yang berbeda mampu mengeliminasi bau langu pada susu ampas tahu ditinjau dari aspek aroma langu, rasa langu, dan rasa essens. Tujuan penambahan
} 
senyawa pengaroma dipertegas oleh Hasanah (2009), tujuan penambahan bahan tambahan makanan yaitu meningkatkan nilai sensoris makanan yakni memperbaiki warna, aroma, rasa dan konsistensi atau tekstur yang sangat penting bagi nilai sensoris makanan -mungkin menurun selama pengolahan dan penyimpanan. Beberapa penurunan dapat dikoreksi atau diperbaiki dengan bahan tambahan seperti pigmen (zat warna), senyawa aroma atau peningkat aroma untuk perbaikan bau yang tidak enak (off flavor) sebagai akibat oksidasi lemak atau minyak.

\section{Kesimpulan}

Berdasarkan data hasil penelitian, dapat disimpulkan bahwa penambahan tepung ampas tahu berpengaruh terhadap mutu kimia yang meliputi kadar air, kadar abu, protein, karbohidrat dan serat serat kasar serta mempengaruhi kualitas sensori crackers yang meliputi warna, tekstur, aroma dan rasa. Dari segi kualitas kimia, crackers dengan komposit tepung ampas tahu terbanyak unggul pada kadar protein dan serat kasar. Namun, dari segi organoleptis crackers dengan komposit tepung ampas tahu yang lebih sedikit lebih disukai oleh panelis.

Pembuatan crackers hasil substitusi tepung terigu dengan tepung ampas tahu melalui uji Metode Perbandingan Eksponensial (MPE) didapatkan perlakuan terbaik adalah pelakuan A (75\% tepung terigu $+25 \%$ tepung ampas tahu) sebagai perlakuan terbaik dengan kadar air 4,56\%, kadar abu 2,46\%, protein $11,00 \%$, serat kasar 3,65\% dan karbohidrat 75,45\%.

\section{Daftar Pustaka}

Anggraini, S. 2012. Eliminiasi Bau Langu Untuk Meningkatkan Kualitas Susu
Ampas Tahu Dengan Pemberian Jenis Essens Dan Volum Essens Yang Berbeda. Jurnal Digital Universitas Negeri Semarang

Engelen, A. 2018. Analisis Kekerasan, Kadar Air, Warna dan Sifat Sensori pada Pembuatan Kripik Daun Kelor. Journal of Agritech Science Vol. 2 No. 1 Tahun 2018

Ferazuma.H., Marliyati.S.H., dan Amalia.L. 2011. Subtitusi Tepung Kepala Ikan Lele Dumbo (Clarias Gariepinus sp) Untuk Meningkatkan Kandungan Kalsium Crackers. Jurnal Gizi dan Pangan, 2011,6(1): 18-27

Hasanah. 2009. Mengenal Bahan Tambahan Makanan. http://hasanahcenter.blogspot.c om/2009/05/mengenal-bahantambahan-makanan-btm.html diakses tanggal 22 September 2019.

Hayati, Nur. 2008. Sifat Kimia Kerupuk Goreng Yang Diberi Penambahan Tepung Daging Sapi dan Perubahan Bilangan Tba Selama Penyimpanan. Skripsi. Teknologi Hasil Ternak. Institut Pertanian bogor. Bogor

Imanningtias N (2008) Mengatasi Off Flavour Pada Formulasi Tempe. http://www. p3gizi.litbang.depkes.go.id.

Diakses pada tanggal 25 Agustus 2019.

Setiaji, B. 2012. Pengaruh Suhu dan Lama Pemanggangan terhadap Karakteristik Soyflakes (Glycine $\max$ L). Skripsi. Universitas Pasundan, Bandung.

Silalahi, R. 2011. Bahan Tambahan Makanan (BTM). Universitas Sumatera Utara, 
http://repository.usu.ac.Id/bitstrea m/123456789/21770/4/Chatr\%20II .pdf. diakses tanggal 22 September 2019.

Sugito dan Hayati. 2006. Penambahan Daging Ikan Gabus dan Aplikasi Pembekuan Pada Pembuatan Pempek Gluten. Jurnal Ilmu-ilmu Pertanian Indonesia 8 (2): 147-151.

Suhardjito, YB. 2006. Pastry Dalam Perhotelan. Yogyakatra: Andi Yogyakarta.

Suhartini dan Hidayat, Nur. 2004. Aneka olahan Ampas Tahu. Surabaya: Trubus Agri Sarana

Suprapti, M. L. 2005. Pembuatan Tahu. Kanisius: Yogyakarta.

Setiaji, B. 2012. Pengaruh Suhu dan Lama Pemanggangan terhadap Karakteristik Soyflakes (Glycine max L). Skripsi. Universitas Pasundan, Bandung.

Syafitri, D. 2009. Pengaruh Substitusi Tepung Ampas Tahu Pada Kue Ulat Sutra Terhadap Kualitas Organoleptik Dan Kandungan Gizi. Skripsi. Fakultas Teknik Universitas Negeri Semarang. Semarang

Wati, R. 2013. Pengaruh Penggunaan Tepung Ampas Tahu sebagai Bahan Komposit Terhadap Kualitas Kue Kering Lidah Kucing. Skripsi. Jurusan Teknologi Jasa dan Produksi Fakultas Teknik Universitas Negeri Semarang.

Wijaya, Hendra. 2010. Kajian Teknis Standar Nasional Indonesia Biskuit SNI 01- 2973-1992. Balai Besar Industri Argo, Kementrian Perindustrian.

Williams dan Margareth, 2001. Food Experimental Perspective, Fourth Edition. Prentice Hall, New Jersey.
Winarno, F.G. 2004. Kimia Pangan dan Gizi. PT Gramedia Pustaka Utama. Jakarta.

Yuliani S dan Mardesci H. 2011. Pengaruh Penambahan Tepung Ampas Tahu Terhadap Karakteristik Biskuit Yang Dihasilkan. Jurnal Teknologi Pangan Vol. 6 No.1 Tahun 2017.

Yustina, I., F.R. Abadi. 2012. Potensi Tepung Ampas Industri Pengolahan Kedelai sebagai Bahan Pangan. Universitas Trunojoyo Madura. Madura. 
Halaman ini sengaja dikosongkan 